\title{
XLVI. Disintegration of the platinum metals in different gases
}

\section{Holborn \& L.W. Austin}

To cite this article: L. Holborn \& L.W. Austin (1904) XLVI. Disintegration of the platinum metals in different gases, Philosophical Magazine Series 6, 7:40, 388-393, DOI:

10.1080/14786440409463131

To link to this article: http://dx.doi.org/10.1080/14786440409463131

Published online: 15 Apr 2009.

Submit your article to this journal $₫$

Џ Article views: 6

Q View related articles $\square$

Citing articles: 1 View citing articles $\square$ 
388 Messrs. Holborn and Austin on Disintegration of

was about $56^{\circ}$, the corresponding refractive index being $1 \cdot 48$.

An attempt was made to determine whether the granulation gave rise to elliptical polarization, the abnormal value of the refractive index suggesting the properties of the surface-films, which play such an important part in the theory of elliptical polarization. No decisive results were obtained, for though the phenomenon was found, it seemed impossible to eliminate the compcnent reflected from the collodionglass surface, which, as I have shown, may, by interference with the component reflected from the air-collodion surface, give rise to an elliptical vibration.

The interferometer failed to show any change in the refractive index as the result of frilling, which indicates that the effect is confined to the surface. A film deposited on glass of such thickness as to produce a shift of half a fringe width (sodium light) was frilled by moisture, one half being protected by a glass plate. No shift was found at the line of demarcation, as would have been the case if the refractive index of the film had been raised from 1.48 to 1.96 throughout its entire thickness.

It is my plan to make a further study of the apparent effect of the granulation on the refractive index of the surface, by the method of total reflexion.

XLVI. Disintegration of the Platinum Metals in Different Gases*. By L. Holbons and L. W. Austint.

7 HE disintegration of the platinum metals at high temperatures appears to be primarily due to their high meltingpoints. The phenomenon which has been observed in many connexions in the case of platinum also occurs with rhodium, palladium, and in a still greater degree with iridium. Observations on the disintegration of these metals in air have been carried out by one of the authors $¥$. The metals were used in the form of strips $3 \mathrm{~mm}$. wide which were heated electrically. The " black temperature," $\mathrm{S}$, was measured by means of the optical pyrometer $\S$, the temperature Celsius, $t$,

* This article in somewhat different form was presented to the Berlin Academy. Sitz. Ber. der Berl. Akad. p. 245 (1903).

+ Communicated by the Authors.

† L. Holborn and F. Henning, Sitz. Ber. p. 938 (1902).

\$ L. Holborn and F. Kurlbaum, Sitz. Ber. p. 712 (1901). 
being calculated from the empirical formula

$$
t=1 \cdot 157 \mathrm{~S}-67 \cdot 2 \text {. }
$$

It was found that the disintegration increased very rapidly with increasing temperature, iridium showing a loss of weiglit of $11.8 \mathrm{mg}$. in an hour at $1210^{\circ} \mathrm{C}, 72 \mathrm{mg}$. at $1670^{\circ}$, and $277 \mathrm{mg}$. at $2130^{\circ}$. At $1670^{\circ}$ platinum and rhodium shower about the same loss in weight, while iridium lost approximately ten times as much. The pure metals showed no decrease in disintegration during the longest heating (:3) hours), the loss appearing to be proportional to the time. Changes were observed, however, in the cases of the platinum-iridium alloys, undoubtedly due to the changes in the composition at the surface on account of the more rapid disintegration of the iridium. Silver and gold heated to $100^{\circ}$ below their melting-points showed no certion loss in weight. We have now extended this work to cover the disintegration in different gases.

Observations on the disintegration of glowing metals in different gases thus far have been confined to platinum and palladium. Elster and Geitel *, and Nahrwold + found, contrary to Berliner $\ddagger$, that platinum showed very little clisintegration in hydrogen. Stewart $\$$ investigated platinum and palladium, and observed that both metals showed little or no disintegration in nitrogen; that in hydrogen, platinum showed no loss in weight and palladium much less than in air. He made no observations with oxygen, but cites an observation by Kaufmann to the effect that in oxygen the disintegratiou of platinum is six times as great as in air. According to Stewart, the disintegration of platinum in air decreases with decreasing pressure, while in the casc of palladium it increases. Emich $\|$ las studied the action of hot platinum in air and in nitric oxide, and has shown that oxygen is taken up by the platinum from the air and from the decomposed nitric oxide.

In the present work the same methods were followed as in the former, except that now it was necessary to decrease the width of the metal strips in order to bring them to the required temperature with a smaller current. These narrower strips, especially in the cuses of the very hard rhodium and iridium, were very difficult to produce of uniform width and

* J. Elster and H. Geitel, Wied. Ann. xxxi. p. 126 (1887).

+ R. Nahrwold, iU. xxx.v. p. 116 (1888).

I A. Berliner, ib. xxxiii. p. 291 (1888).

\$ W. Stewart, ib. lxvi. p. 88 (1898); Phil. Mag. [5] xlviii. p. 481 (1899).

॥ F. Emich, Sitz.-Ber. der. Wienor Akademie, ci. [2 b], p. 88 (1892). 
without irregularities. The different strips could not therefore be properly compared with one another, but this was not of great moment as the chief object of the work was the comparison of the disintegration of the same strip under different conditions.

The $75 \mathrm{~mm}$. long strips were clamped to $6 \mathrm{~mm}$. thick copper wires and the whole introduced into a glass tube (fig. 1) $12 \mathrm{~cm}$. in diameter, by means of a ground-glass connexion. The copper wires were cemented into the gliss with sealing-wax. All the other external connexions of the tube were rendered tight with mercury. The tube was also provided with a side tube containing $\mathrm{P}_{2} \mathrm{O}_{5}$ to be used at low gas pressures. The current was introduced through mereury cups in which the ends of the copper wires rested.

The metal strips were too narrow for direct comparison with the optical

Fig. I.

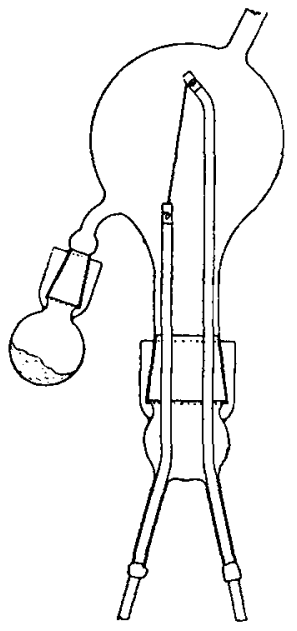
pyrometer, therefore a $3 \mathrm{~mm}$. wide, electrically heated platinum band was brought to the required temperature. Against this the metal strip in the tube was projected, and heated until it attained the same degree of brightness.

Contrary to the observations on the broad metal strips, al diminution of the disintegration with the time was often observed. This was due to the fact that the narrow strips, on account of the disintegration, soon became thinner in the central hottest zone; and if this was kept at a constant temperature by reducing the eurrent, the length over which the disintegration took place became constantly shorter. In the cases where the disintegration was most rapid, we have therefore not used the highest possible temperatures and have also reduced the usual 30 minutes time of heating, in order to prolong the uniformity of the strips and to enable a greater number of comparisons to be made. Another reason for reducing the amount of the disintegration was that the transparency of the tube was rapidly destroyed by the metallic deposits which had to be frequently removed between the observations.

The weighings were made on a balance having a sensibility of about three divisions for $0.1 \mathrm{mg}$, and are certain to $0.01 \mathrm{mg}$. 
TABLE.

\begin{tabular}{|c|c|c|c|c|c|c|}
\hline & $\begin{array}{c}\text { Temp } \\
\text { S. } \\
\text { (Black). }\end{array}$ & $\begin{array}{l}\text { enture. } \\
t . \\
\text { (Celsins) }\end{array}$ & Gas. & $\begin{array}{l}\text { Pressure } \\
\text { wm. Hg. }\end{array}$ & $\begin{array}{l}\text { Time. } \\
\text { Mis. }\end{array}$ & $\begin{array}{c}\text { Loss in } \\
30 \mathrm{Min} . \\
\mathrm{mg} .\end{array}$ \\
\hline $\begin{array}{l}\text { Platinum } \\
\text { Width } 1.0 \mathrm{~mm} \text {. } \\
\text { Thickness } 0.1 \mathrm{~mm} \text {. }\end{array}$ & $\begin{array}{c}1500^{\circ} \\
", \\
", \\
", \\
1150 \\
1050 \\
",\end{array}$ & $\begin{array}{c}1670^{\circ} \\
": \\
" \\
", \\
1 \% \\
1160 \\
1150 \\
",\end{array}$ & $\begin{array}{c}\text { Air } \\
\ddot{O} \\
\stackrel{\mathbf{N}}{\mathrm{H}} \\
\ddot{A} \ddot{i r} \\
\ddot{O}\end{array}$ & $\begin{array}{c}760 \\
25 \\
760 \\
\ddot{25} \\
0.2 \\
760 \\
", \\
"\end{array}$ & $\begin{array}{c}30 \\
" \\
" \\
\ddot{15} \\
\ddot{30} \\
",\end{array}$ & $\begin{array}{l}0 \cdot 68 \\
0 \cdot 32 \\
3 \cdot 41 \\
0 \cdot 05 \\
0 \cdot 03 \\
0 \cdot 00 \\
0 \cdot 03 \\
0 \cdot 01 \\
0.04\end{array}$ \\
\hline $\begin{array}{l}\text { Rhodium. } \\
\text { Width } 0.8 \mathrm{~mm} \text {. } \\
\text { Thickness } 0.3 \mathrm{~mm} \text {. }\end{array}$ & $\begin{array}{c}1500 \\
", \\
" \\
"\end{array}$ & $\begin{array}{c}1670 \\
, " \\
" \\
"\end{array}$ & $\begin{array}{l}\text { Air } \\
\ddot{O} \\
\mathbb{N}\end{array}$ & $\begin{array}{c}760 \\
205 \\
760 \\
" 1\end{array}$ & $\begin{array}{l}30 \\
", \\
",\end{array}$ & $\begin{array}{l}0.9 \\
0.14 \\
1.60 \\
005\end{array}$ \\
\hline $\begin{array}{l}\text { Iridium. } \\
\text { Width } 0.7 \mathrm{~mm} . \\
\text { Thickness } 0.35 \mathrm{~mm} .\end{array}$ & $\begin{array}{c}1500 \\
, \\
, \\
",\end{array}$ & $\begin{array}{c}1670 \\
" \\
" \\
"\end{array}$ & $\begin{array}{l}\text { Air } \\
\ddot{O} \\
\dot{N}\end{array}$ & $\begin{array}{c}760 \\
25 \\
760 \\
,\end{array}$ & $\begin{array}{l}15 \\
30 \\
10 \\
30\end{array}$ & $\begin{array}{c}12 \cdot 57 \\
1 \cdot 61 \\
134.5 \\
0 \cdot 46\end{array}$ \\
\hline $\begin{array}{l}\text { Iridium. } \\
\text { Width } 0.8 \mathrm{~mm} \text {. } \\
\text { Thickness } 0.1 \mathrm{~mm} \text {. }\end{array}$ & $\begin{array}{l}1500 \\
1150\end{array}$ & $\begin{array}{l}1670 \\
1260\end{array}$ & $\begin{array}{l}\mathrm{H} \\
\mathrm{Air}\end{array}$ & $\begin{array}{c}0 \cdot 3 \\
760\end{array}$ & $\begin{array}{l}15 \\
10\end{array}$ & $\begin{array}{l}0.04 \\
0.78\end{array}$ \\
\hline $\begin{array}{l}90 \text { Pt., } 10 \mathrm{Ir} \text {. } \\
\text { Width } 0.5 \mathrm{~mm} . \\
\text { Thickness } 0.2 \mathrm{~mm} \text {. }\end{array}$ & $\begin{array}{l}1500 \\
",\end{array}$ & $\begin{array}{l}1670 \\
": \\
":\end{array}$ & $\stackrel{\mathrm{Air}}{\mathrm{O}}$ & $\begin{array}{l}760 \\
, " \\
,\end{array}$ & $\begin{array}{l}30 \\
" \\
"\end{array}$ & $\begin{array}{l}1 \cdot 47 \\
3 \cdot 72 \\
0 \cdot 16\end{array}$ \\
\hline $\begin{array}{l}\text { Palladium. } \\
\text { Width } 10 \mathrm{~mm} \text {. } \\
\text { Thickness } 0.1 \mathrm{~mm} \text {. }\end{array}$ & $\begin{array}{c}1350 \\
", \\
", \\
1300 \\
", \\
1250 \\
1150\end{array}$ & $\begin{array}{c}1500 \\
", \\
", \\
1440 \\
" " \\
1380 \\
1260\end{array}$ & $\begin{array}{c}\text { Air } \\
\ddot{O} \\
\text { N } \\
\text { Air } \\
\text { H } \\
\text { Är } \\
"\end{array}$ & $\begin{array}{c}760 \\
25 \\
760 \\
\ddot{2} \\
25 \\
30 \\
0 \cdot 2 \\
760 \\
",\end{array}$ & $\begin{array}{l}30 \\
10 \\
30 \\
10 \\
10 \\
15 \\
15 \\
30 \\
.,\end{array}$ & $\begin{array}{r}1 \cdot 00 \\
7 \cdot 29 \\
0.74 \\
1.12 \\
1.09 \\
1.166 \\
10.85 \\
0.06 \\
0.01\end{array}$ \\
\hline
\end{tabular}

The observations on each metal were made in the following order :-

1. At atmospheric pressure, the tube being left open at top and bottom to allow a free cireulation of air.

2 . With the tube pumped out to a water vacuum.

3. With a slow stream of commercial oxygen or nitrogen passing slowly through the tube.

4. With the tube filled with hydrogen at different pressures. 
The loss of weight which is given in the last column of the table is in most cases the mean of several observations. The values are calculated for $\mathbf{3 0}$ minutes heating, the actual time being given in the last column but one.

As the table shows, the behaviour of platinum and rhodium is very similar. The disintegration at atmospheric pressure in oxygen is about five times as great as in air, in air at $25 \mathrm{~mm}$. about half as much as at $760 \mathrm{~mm}$., and in nitrogen it becomes very small. That it does not disappear entirely, is probably due to the 1.7 per cent. of oxygen that was mixed with the nitrogen. In the work with the broad strips it was found that the loss of weight of platinum and rhodium under the same circumstances was the same. The differences here shown in the two metals are due to the fact that on account of its irregular width the rhodium strip reached the disintegration temperature in only a comparatively narrow zone. Iridium, which disintegrates about ten times as rapidly in the air as platinum, behaves in a similar way except that the differences are much greater. At $25 \mathrm{~mm}$. pressure its loss in weight is only $\frac{1}{8}$ that at $760 \mathrm{~mm}$, while in oxygen the loss is eleven times as great.

In palladium the phenomena were entirely different. The disintegration in air increased with decreasing pressure, while the nature of the surrounding gas seemed to be without influence, the results being the same in air, oxygen, and nitrogen. According to Stewart, palladium, like platinum, should show little disintegration in nitrogen.

For the experiments in hydrogen the gas was prepared electrolytically, and freed from oxygen by passing through several wash-bottles containing alkaline pyrogallol solution, and dried by passing through tubes of calcium chloride and phosphorus pentoxide. The whole apparatus was several times pumped out and filled with hydrogen before the final filling.

The experiments with palladium in hydrogen were difficult on account of the absorption of the gas by the metal. It was not found possible at atmospheric pressure to keep the metal for any length of time above the temperature where the disintegration begins. In most cases it melted before reaching this temperature, and also showed an increase in weight due to the absorbed gas, which made any attempt at measuring the disintegration impossible. At lower pressures the experiments were more successful. During the preliminary fillings and pumpings, the palladium was kept at a dull red heat. Finally, when hydrogen was admitted until the pressure reached $30 \mathrm{~mm} . \mathrm{Hg}$, and the temperature was 
increased to $S=1300^{\circ}$ and there kept constant, the loss in weight was practically the same as in air at the same pressure. The disintegration increased rapidly as the pressure was reduced, until at $0.2 \mathrm{~mm}$. Hg it was more than ten times as great as at $30 \mathrm{~mm}$. The disintegrated particles in this case formed a brilliant metallic deposit on the copper wires in the tube, whereas when oxygen was present the deposit- werc always black.

Platinum and iridium were also heated in the high hydrogen vacuum, but showed no disintegration. A few obscration. were made at lower temperatures where the disintegration first begins to appear. Iridium showed a loss of weight at the lowest temperature, but the results were irregular since the metal was oxidized at this temperature. Experimentwith gold in oxygen were also attempted, but no trices of disintegration were observed.

This investigation has a practical bearing on high-temperalture work in general. Platinum heating-coils when brought. too near the melting-point of the metal are rapidly destroyed, and the case is still worse with iridium, which otherwise on account of its high melting-point would be particularly suited for use in producing high temperatures. Our results indicate means by which the platinum metals may be protected from disintegration.

Physikalisch-Technische Reichsanstalt, Charlottenburg, Feb. 1904.

XLVII. A Quartz-Thead Tertical Firre Mlagnetorraph. By W. Watson, A.R.C.S., T.Se., F.R.S., Assistint Profisson. of Physics at the Royal College of Science, London *.

rplates XXII. \& XXIII.

THE late Dr. Eschenhagen was the first to show that when the moment of inertia of the suspended system in a horizontal-force magnetograph is made very much smaller than that employed in the ordinary form, it is possible to detect rariations in the earth's field of quick period. Since the study of these short-period variations promises to be of considerable interest, the design of self-recording instrument: capable of giving satisfactory records becomes of importance. Both Dr. Eschenhagen $\dagger$ and the author $\ddagger$ have described

* Communicated by the Plysical Society: read February 26, 1904.

+ 'T'errestrial Magnetism,' v. p. 59 (1900).

t Ibid. vi. p. 187 (1901). 